\title{
Synthesis, spectroscopic characterization and antimicrobial studies of mercury(II) complexes of thiolates
}

\author{
Ghulam Rabbani ${ }^{\text {a }}$, Anvarhusein A. Isab ${ }^{\text {b,* }}$, Abdul Rahman Al-Arfaj ${ }^{\text {b }}$, Saeed Ahmad ${ }^{\text {a }}$, \\ Muhammad Saleem ${ }^{\mathrm{c}}$, Abdul Hameed ${ }^{\mathrm{c}}$ and Erum Akbar ${ }^{\mathrm{a}}$ \\ ${ }^{a}$ Department of Chemistry, University of Engineering and Technology, Lahore, Pakistan \\ ${ }^{\mathrm{b}}$ Department of Chemistry, King Fahd University of Petroleum and Minerals, Dhahran, Saudi Arabia \\ ${ }^{\mathrm{c}}$ PAEC, Islamabad GPO, Pakistan
}

\begin{abstract}
Mercury(II) complexes of thiolates having the general formula $\left[\mathrm{Hg}(\mathrm{RS}) \mathrm{Cl}_{2}\right]^{-}$and $\left[\mathrm{Hg}(\mathrm{RS})_{2}\right]$ have been prepared and characterized by IR and NMR $\left({ }^{1} \mathrm{H}\right.$ and $\left.{ }^{13} \mathrm{C}\right)$ spectroscopy (RSH $=2$-aminoethanethiol hydrochloride (Aet), cysteine (Cys), thiosalicylic acid (Ts) and 2-mercaptonicotinic acid (Mnt)). The spectral data suggests that the coordination of thiolates to mercury(II) occurs through the sulfur as indicated by the absence of S-H vibrations in IR and significant downfield shifts in the $\mathrm{C}-\mathrm{S}$ resonance in ${ }^{13} \mathrm{C}$ NMR. However, in Mnt complexes, coordination through both sulfur and nitrogen is indicated. Antimicrobial activities of the complexes were evaluated by minimum inhibitory concentration and the results showed that the complexes exhibited a wide range of activities against gram-negative bacteria (E. coli, P. aeruginosa), while moderate activity was observed against a mold, P. citrinum.
\end{abstract}

Keywords: Mercury(II), thiolates, NMR spectroscopy, antimicrobial activity

\section{Introduction}

The interaction of mercury(II) with sulfur-containing molecules is an important area in bioinorganic chemistry because such studies provide models for naturally occurring sulfur-containing compounds [1-10]. The biological chemistry of mercury is dominated by coordination to cysteine thiolate groups in agreement with the preference of this metal ion for the soft sulfur ligands and a great deal of research has been conducted to understand how the amino acid interacts with metals [11-15]. Several types of cysteine derivatives (e.g., pencillamine and $N$-actylcysteine) form soluble complexes and have been suggested as possible detoxification agents [16-19]. Although mercury(II) being a soft Lewis acid forms quit stable complexes with thiol groups [20-23], many thiolates remain labile and undergo ligand exchange, which is more pronounced in low (two and three)-coordinate compounds [24,25]. Mercurythiolates provide representative examples of the structural diversity shown by the extensive family of metal thiolates [5-8,13,26-28]. They are well known for their unusual coordination environment and exhibit structural variability both in the solution form and solid states. Thiols combine with a mercury halide to form complicated clusters or polymeric structures containing $\mathrm{Hg}-\mathrm{S}$ and in some cases

\footnotetext{
${ }^{*}$ Corresponding author: Anvarhusein A. Isab, Department of Chemistry, King Fahd University of Petroleum and Minerals, Dhahran 31261, Saudi Arabia. E-mail: aisab@kfupm.edu.sa.
} 


$$
\text { HS }-\stackrel{1}{\mathrm{CH}_{2}} \stackrel{2}{-} \mathrm{CH}_{2}-\mathrm{NH}_{2} \cdot \mathrm{HCl}
$$

2-aminoethanethiol hydrochloride Cysteine<smiles>O=C(O)c1ccccc1S</smiles><smiles>O=C(O)c1cccnc1S</smiles>

Thiosalicylic acid

2-mercaptonicotic acid

Scheme 1. Structures of thiolates used in this study and their resonance assignment.

$\mathrm{Hg}-\mathrm{X}$ interactions [5-8, 15,23,28]. Homoleptic thiolates of mercury(II) can be mononuclear $\left(\mathrm{Hg}(\mathrm{SR})_{2}\right.$, $\left.\mathrm{Hg}(\mathrm{SR})_{3}, \mathrm{Hg}(\mathrm{SR})_{4}\right)$, dinuclear $\left(\mathrm{Hg}_{2}(\mathrm{SR})_{3}, \mathrm{Hg}_{2}(\mathrm{SR})_{6}\right)$, trinuclear $\left(\mathrm{Hg}_{3}(\mathrm{SR})_{4}\right)$, tetranuclear $\left(\mathrm{Hg}_{4}(\mathrm{SR})_{6}\right)$, pentanuclear $\left(\mathrm{Hg}_{5}(\mathrm{SR})_{8}\right)$, or polynuclear $\left(\left[\mathrm{Hg}(\mathrm{SR})_{n}\right]_{\infty}\right)$ (and with variable charge depending on the $\mathrm{R}$ group) [12,27-32]. In contrast, heteroleptic thiolates of mercury(II) (i.e. containing both monodentate thiolate and halide) are polymeric and either one dimensional $\left(\left[\mathrm{Hg}(\mathrm{SR}) \mathrm{Cl}_{2}\right]_{\infty}\right)$ or two dimensional $\left([\mathrm{Hg}(\mathrm{SMe}) \mathrm{X}]_{\infty}(\mathrm{X}=\mathrm{Cl}\right.$ or $\mathrm{Br})$ and $\left.\left[\mathrm{Hg}\left(\mathrm{SPr}^{i}\right) \mathrm{Cl}\right]_{\infty}\right)$ [33-35]. As an attempt to explore further the chemistry of mercury-thiolates, the present study describes the synthesis of mercury complexes with thiolates and their characterization by IR and NMR $\left({ }^{1} \mathrm{H}\right.$ and $\left.{ }^{13} \mathrm{C}\right)$ spectroscopic methods. The structures of ligands used in this study and their resonance assignments are described in Scheme 1.

\section{Experimental procedure}

\subsection{Chemicals}

Mercury(II) chloride was obtained from Merck Chemical Co., Germany. Cysteine (Cys), 2-aminoethanethiol hydrochloride (Aet), thiosalisylic acid (Ts) and 2-mercatonicotinic acid (Mnt), were purchased from Acros Organics, Belgium.

\subsection{Spectroscopic measurements}

The solid state IR spectra of the ligands and their mercury(II) complexes were recorded on a PerkinElmer FTIR 180 spectrophotometer using KBr pellets over the frequency range $4000-400 \mathrm{~cm}^{-1}$. The ${ }^{1} \mathrm{H}$ NMR spectra of the complexes in DMSO- $\mathrm{d}_{6}$ were obtained on Jeol JNM-LA 500 NMR spectrometer operating at a frequency of $500.00 \mathrm{MHz}$ at $297 \mathrm{~K}$. The ${ }^{13} \mathrm{C}$ NMR spectra were obtained at the frequency of $125.65 \mathrm{MHz}$ with ${ }^{1} \mathrm{H}$ broadband decoupling. The spectral conditions were: $32 \mathrm{k}$ data points, $0.967 \mathrm{~s}$ acquisition time, $1.00 \mathrm{~s}$ pulse delay and $45^{\circ}$ pulse angle. The ${ }^{13} \mathrm{C}$ chemical shifts were measured relative to TMS.

\subsection{Synthesis of the complexes}

The complexes were prepared by adding 1 or 2 equivalents of thiolates in methanol (cysteine was dissolved in distilled water, while 2-mercaptonicotinic acid was taken as suspension in methanol) to $0.271 \mathrm{~g}(1 \mathrm{mmol})$ of $\mathrm{HgCl}_{2}$ in methanol and stirring the mixture for 25-30 min. Mixing of the two solutions resulted in precipitates that were filtered, washed with methanol and air-dried. The isolated complexes are white except for the Mnt complexes, which are light yellow. The product yield is about $70-80 \%$. The melting points of the complexes are given in Table 1. 
Table 1

Melting points and selected IR absorptions $\left(\mathrm{cm}^{-1}\right)$ of mercury(II)-thiolate complexes

\begin{tabular}{lcccc}
\hline Species & m.p. $\left({ }^{\circ} \mathrm{C}\right)$ & $\nu(\mathrm{C}-\mathrm{S})$ & $\nu(\mathrm{N}-\mathrm{H})$ & $\nu(\mathrm{C}=\mathrm{O})$ \\
\hline Aet & - & 757 & & - \\
{$\left[\mathrm{Hg}(\mathrm{Aet}) \mathrm{Cl}_{2}\right]$} & 220 & 670 & 3446,3088 & - \\
{$\left[\mathrm{Hg}(\mathrm{Aet})_{2} \mathrm{Cl}_{2}\right]$} & 214 & 670 & 3455,3056 & - \\
$\mathrm{Cys}$ & - & 678 & 3179 & 1627 \\
{$[\mathrm{Hg}(\mathrm{Cys}) \mathrm{Cl}]$} & 170 & 675 & 3125 & 1678 \\
{$\left[\mathrm{Hg}(\mathrm{Cys})_{2}\right]$} & 184 & 675 & 3124 & 1678 \\
$\mathrm{Ts}$ & - & 651 & - & 1681 \\
{$[\mathrm{Hg}(\mathrm{Ts}) \mathrm{Cl}]$} & 280 & 644 & - & 1674 \\
{$\left[\mathrm{Hg}(\mathrm{Ts})_{2}\right]$} & 260 & 646 & - & 1670 \\
$\mathrm{Mnt}$ & - & 640 & - & 1682 \\
{$[\mathrm{Hg}(\mathrm{Mnt}) \mathrm{Cl}]$} & 240 & 643 & - & 1721 \\
{$\left[\mathrm{Hg}(\mathrm{Mnt})_{2}\right]$} & 250 & 643 & - & 1721 \\
\hline
\end{tabular}

\subsection{Antimicrobial studies of the complexes}

Antimicrobial activities of the mercury(II) compounds prepared here were estimated by minimum inhibitory concentration (MIC; $\mu \mathrm{g} \mathrm{ml}^{-1}$ ) [36]. Standard culture media of bacteria, Escherichia coli (ATCC 13706) and Pseudomonas aeruginosa (MTCC 424), and molds, Aspergillus niger (MTCC 1349) and Penicillium citrinum (MTCC 5215) were obtained from Qingdao Yijia Huuyi Co., China. Bacteria were inoculated into $5 \mathrm{ml}$ of liquid SCD medium (soybean, casein and digest) and cultured for $24 \mathrm{~h}$ at $35.5^{\circ} \mathrm{C}$. The cultured fluids were diluted, adjusted to a concentration of $10^{5}-10^{6}$ microorganisms per $\mathrm{ml}$ and used for inoculation in the MIC test. In the case of mold culture, the agar slant (potato and dextrose) medium for one week cultivation at $27^{\circ} \mathrm{C}$ was gently washed with saline containing $0.05 \%$ Tween 80 . The spore suspension obtained was adjusted to the concentration of $10^{5}$ microorganisms per $\mathrm{ml}$ and used for inoculation in the MIC test. The test materials (mercury(II) complexes) were suspended in water, and solutions were then diluted with SCD medium for bacteria and with GP medium (glucose and polypeptone) for mold. Using them the two-fold diluted solutions with concentrations of $1000 \mathrm{mg} \mathrm{ml}^{-1}$ to $10 \mathrm{mg} \mathrm{ml}^{-1}$ were prepared. Each $1 \mathrm{ml}$ of culture medium containing various concentrations of test materials was inoculated with $0.1 \mathrm{ml}$ of the microorganism suspension prepared above. Bacteria were cultured for $24 \mathrm{~h}$ at $35.5^{\circ} \mathrm{C}$ and mold for 7 days at $25^{\circ} \mathrm{C}$. Growth of the microorganisms was monitored during this period. When no growth of microorganism was observed in the medium containing the lowest concentration of test materials, the MIC of the test material was defined at this point of dilution.

\section{Results and discussion}

The reaction of $\mathrm{HgCl}_{2}$ with thiolates in a 1:1 or 1:2 molar ratio in methanol or methanol-water media resulted in a product of composition of the $\left[\mathrm{Hg}(\mathrm{RS})_{2}\right]$ or $\left[\mathrm{Hg}(\mathrm{RS}) \mathrm{Cl}_{2}\right]^{-}$. The differential thermal analysis (DTA) of both types of complexes exhibited the endothermic transitions at different temperatures between $200-300^{\circ} \mathrm{C}$ suggesting that different compounds were formed in both cases. The most significant IR frequencies of the ligands and their mercury(II) complexes are summarized in Table 1. In all the IR spectra, disappearance of S-H peak at around $2550-2500 \mathrm{~cm}^{-1}$ indicates that the S-H bonds in ligands have been replaced by the $\mathrm{S}-\mathrm{Hg}$ bond in complexes, showing high affinity of sulfur towards 
$\mathrm{Hg}(\mathrm{II})$. A significant change in the $\mathrm{C}-\mathrm{S}$ stretches of all complexes with respect to free ligands also suggests the $\mathrm{Hg}-\mathrm{S}$ coordination. The IR spectra of cysteine and Aet complexes show the presence of $\mathrm{N}-\mathrm{H}$ stretching frequencies at around 3400 and $3100 \mathrm{~cm}^{-1}$. In Aet, the two bands are indicative of $\mathrm{NH}_{3}{ }^{+}$ group rather than $\mathrm{NH}_{2}$. Similar observation for the presence of $\mathrm{NH}_{3}{ }^{+}$groups were made in $\left[\mathrm{Cd}\left(\mathrm{NH}_{3}-\right.\right.$ $\left.\mathrm{CH}-\left(\mathrm{CH}_{2}-\mathrm{SH}\right) \mathrm{COO}\right)_{2}$ ] (3404 and $\left.3010 \mathrm{~cm}^{-1}\right)$ [37]. Also, peaks at around 1600 and $1470 \mathrm{~cm}^{-1}$ can be assigned to symmetric deformations and degenerate deformation modes, respectively, for $\mathrm{NH}_{3}{ }^{+}$group [7]. These values are lower than those in free ligand $\left(1690\right.$ and $\left.1484 \mathrm{~cm}^{-1}\right)$ showing its involvement in hydrogen bonding. Similar peaks have been observed for mercury complexes with L-cysteine (1606 and $\left.1487 \mathrm{~cm}^{-1}\right)$ and for L-cysteine methyl ester (1582 and $\left.1495 \mathrm{~cm}^{-1}\right)$ [17]. A sharp band around $1700 \mathrm{~cm}^{-1}$ was observed for $\mathrm{C}=\mathrm{O}$ stretch of thiolates except in Aet complexes.

In proton NMR spectra of the complexes, disappearance of the $\mathrm{S}-\mathrm{H}$ signal indicates the replacement of S-H hydrogen by mercury(II) ions. In the spectra of $\mathrm{Hg}-$ Aet complexes, a significant downfield shift of the methylene protons attached to sulfur is observed with respect to the free ligands (3.06 and 3.15 for Aet1 and Aet2, respectively, vs. $2.69 \mathrm{ppm}$ ) showing the binding of mercury(II) to sulfur. These values are comparable to those for $\left[\mathrm{Hg}_{3} \mathrm{Cl}_{5}\left(\mathrm{SCH}_{2} \mathrm{CH}_{2} \mathrm{NH}_{3}\right)_{3} \mathrm{Cl}\right]_{n}$ (3.08) and $\left[\mathrm{Hg}_{6} \mathrm{Cl}_{8}\left(\mathrm{SCH}_{2} \mathrm{CH}_{2} \mathrm{NH}_{3}\right)_{8}\right] \mathrm{Cl}_{4}$. $4 \mathrm{H}_{2} \mathrm{O}(3.14 \mathrm{ppm})$, while they are lower than in $\left[\mathrm{Hg}\left(\mathrm{SCH}_{2} \mathrm{CH}_{2} \mathrm{NH}_{3}\right)_{2}\right]^{+}$(3.27 ppm) [5-7]. Appearance of almost similar resonances for the $\mathrm{N}-\mathrm{CH}_{2}$ protons to that of free ligand $(\sim 3.0 \mathrm{ppm})$ indicates that $\mathrm{Hg}-\mathrm{N}$ contact is absent. Also the resonances at about $7.8 \mathrm{ppm}$ show the presence of $\mathrm{NH}_{3}{ }^{+}$group in the complexes. The integration of amine protons $(\mathrm{NH}: \mathrm{CH}$ protons $=1: 1.4)$ indicates the presence of an ammonium group, $\mathrm{NH}_{3}{ }^{+}$rather than $\mathrm{NH}_{2}$. Similarly, in $\mathrm{Hg}-\mathrm{Cys}$ complexes a downfield shift of about $0.5 \mathrm{ppm}$ was recorded in $\mathrm{CH}_{2}$ protons of cysteine (3.5 vs. $3.0 \mathrm{ppm}$ ). The ${ }^{1} \mathrm{H}$ NMR spectra of Ts and Mnt complexes display resonances at 7.0-8.35 ppm for aromatic protons that can be assigned easily. In Ts, the protons at C-3 and C-4 appear as doublets, while the other two appear as triplets at 7.973, 7.56, 7.436 and $7.250 \mathrm{ppm}$, respectively. The C-2, C-3 and C-4 protons of Mnt are observed at 8.552, 7.166 and 8.188 ppm, respectively. Except in C-2 proton of Mnt, no significant change in chemical shift is observed in the aromatic protons upon complexation, since they are not involved directly in binding. The $\mathrm{C}-\mathrm{N}$ proton of Mnt has shifted $0.2 \mathrm{ppm}$ upfield showing coordination by nitrogen atom.

The ${ }^{13} \mathrm{C}$ chemical shifts of the ligands and complexes are summarized in Table 2 . The assignment of Ts and Mnt resonances is based on the peak intensities, electronegativity relationships and the splitting pattern of aromatic protons in ${ }^{1} \mathrm{H}$ NMR. In the ${ }^{13} \mathrm{C}$ NMR spectra for all complexes, a prominent downfield shift is observed for the $\mathrm{C}-\mathrm{S}$ resonance with respect to that of free ligands indicating the binding of mercury(II) to sulfur atom of thiolates. The strength of the binding can be estimated by the magnitude of chemical shift changes in ${ }^{13} \mathrm{C}$ NMR. The greatest shift in Ts resonances suggests its strongest binding capacity among these thiolates. The difference in C-S shift of 3-4 ppm in Aet and Cys complexes shows their comparable binding capacity. In the complexes of cysteine and Aet, the $\mathrm{C}-\mathrm{N}$ resonance, however, does not show profound shift with respect to free ligands, supporting that nitrogen is not involved in coordination in these complexes. In Mnt complexes, significant downfield shifts are also observed in the $\mathrm{C}-\mathrm{N}$ resonance indicating that nitrogen atom of $\mathrm{Mnt}$ is also involved in binding to mercury(II). Similar downfield shifts have been observed for a Pd(II)-Mnt complex that involves both the sulfur and nitrogen atoms of Mnt in metal binding and this observation was also supported by the X-ray structure of the complex [38].

We could not get any of these compounds in the crystalline form; therefore, their X-ray analysis could not be carried out. However, the spectral data presented here would be useful for the study of mercury interaction with sulfur-containing biomolecules, and understanding the role of thiolates in detoxification of mercury. 
Table 2

${ }^{13} \mathrm{C}$ chemical shifts $(\delta)$ of thiolates and their $\mathrm{Hg}(\mathrm{II})$ complexes in DMSO

\begin{tabular}{|c|c|c|c|c|c|c|}
\hline Species & $\mathrm{C}-1$ & $\mathrm{C}-2$ & $\mathrm{C}-3$ & C-4 & $\mathrm{C}-5$ & $\mathrm{C}=\mathrm{O}$ \\
\hline$\overline{\text { Aet }}$ & 22.0 & 42.0 & - & - & - & - \\
\hline$\left[\mathrm{Hg}(\right.$ Aet $\left.) \mathrm{Cl}_{2}\right]$ & 25.85 & 42.90 & - & - & - & - \\
\hline$\left[\mathrm{Hg}(\mathrm{Aet})_{2} \mathrm{Cl}_{2}\right]$ & 26.73 & 42.67 & - & - & - & - \\
\hline Cys & $25.5^{\mathrm{a}}$ & $56.6^{\mathrm{a}}$ & - & - & - & $173.0^{\mathrm{a}}$ \\
\hline$[\mathrm{Hg}(\mathrm{Cys}) \mathrm{Cl}]$ & 28.95 & 55.68 & - & - & - & 170.50 \\
\hline$\left[\mathrm{Hg}(\mathrm{Cys})_{2}\right]$ & 28.85 & 55.37 & - & - & - & 170.12 \\
\hline Ts & 126.56 & 131.43 & 130.95 & 124.62 & $\begin{array}{c}132.47 \\
(138.21)^{b}\end{array}$ & 167.65 \\
\hline$[\mathrm{Hg}(\mathrm{Ts}) \mathrm{Cl}]$ & 134.42 & 130.95 & 130.05 & 125.66 & $\begin{array}{c}135.69 \\
(137.07)^{b}\end{array}$ & 169.88 \\
\hline$\left[\mathrm{Hg}(\mathrm{Ts})_{2}\right]$ & 134.88 & 130.75 & 129.82 & 125.48 & $\begin{array}{c}135.62 \\
(137.13)^{b}\end{array}$ & 169.93 \\
\hline Mnt & 173.2 & 143.9 & 115.0 & 143.1 & 129.4 & 165.1 \\
\hline$[\mathrm{Hg}(\mathrm{Mnt}) \mathrm{Cl}]$ & 170.73 & 147.29 & 118.98 & 141.49 & 128.85 & 166.58 \\
\hline$\left[\mathrm{Hg}(\mathrm{Mnt})_{2}\right]$ & 169.27 & 146.06 & 117.25 & 142.10 & 128.57 & 166.04 \\
\hline
\end{tabular}

${ }^{\mathrm{a}}$ Values in $\mathrm{D}_{2} \mathrm{O}$; ${ }^{\mathrm{b}}$ chemical shift of $\mathrm{C}-6$.

Table 3

Antimicrobial activities of mercury(II)-thiolate complexes evaluated by the minimum inhibitory concentration (MIC: $\mu \mathrm{g} \mathrm{ml}{ }^{-1}$ )

\begin{tabular}{lcccr}
\hline Complexes & \multicolumn{4}{c}{ Microbial activity (in terms of MIC: $\mu \mathrm{g} \mathrm{ml}^{-1}$ ) } \\
\cline { 2 - 5 } & Escherichia coli & Pseudomonas aeruginosa & Aspergillus niger & Penicillium citrinum \\
\hline$\left[\mathrm{Hg}(\mathrm{Aet}) \mathrm{Cl}_{2}\right]$ & 120 & 60 & $>1000$ & 90 \\
{$\left[\mathrm{Hg}(\mathrm{Aet})_{2} \mathrm{Cl}_{2}\right]$} & 90 & 20 & $>1000$ & 70 \\
{$[\mathrm{Hg}(\mathrm{Cys}) \mathrm{Cl}]$} & 50 & 30 & $>1000$ & 80 \\
{$\left[\mathrm{Hg}(\mathrm{Cys})_{2}\right]$} & 80 & 40 & $>1000$ & 250 \\
{$[\mathrm{Hg}(\mathrm{Ts}) \mathrm{Cl}]$} & 960 & 710 & $>1000$ & $>1000$ \\
{$\left[\mathrm{Hg}(\mathrm{Ts})_{2}\right]$} & 1000 & $>1000$ & $>1000$ & $>1000$ \\
{$[\mathrm{Hg}(\mathrm{Mnt}) \mathrm{Cl}]$} & 960 & $>1000$ & $>1000$ & $>1000$ \\
{$\left[\mathrm{Hg}(\mathrm{Mnt})_{2}\right]$} & 850 & &
\end{tabular}

\subsection{Antimicrobial activities}

The antimicrobial activities of the mercury(II) complexes (average of three measurements) estimated by minimum inhibitory concentrations (MIC; $\mu \mathrm{g} \mathrm{ml}^{-1}$ ) are listed in Table 3 . Table 3 shows that the tested complexes displayed wide range of activity against two gram-negative bacteria (E. coli, P. aeruginosa) and moderate activity against a mold, $P$. citrinum. However, tested complexes did not show any activity against the mold, A. niger. Similarly no antimicrobial activity of Ts and Mnt complexes was noted against $P$. citrinum. This fact could be attributed to whether or not the complexes possess the tendency to further ligand replacement with the biological ligands such as proteins and DNA. The complexes of Aet and Cys ligands particularly possess significant activities against the bacteria and a mold, P. citrinum. This suggests that mercury is labile in these complexes with replacement by biological ligands being possible. The presence of $\mathrm{C}-\mathrm{NH}_{2}$ bonding may play a role in the antimicrobial activities. In case of Ts and Mnt complexes, probably a stable chelate is formed due to which the ligands could not be displaced easily by biological ligands and as a result the activities are poor. 


\section{Acknowledgements}

Financial support from Pakistan Council for Science and Technology, Islamabad, Pakistan and from King Fahd University of Petroleum \& Minerals, Dhahran, Saudi Arabia is gratefully acknowledged.

\section{References}

[1] P.J. Blowers and J.R. Dilworth, Coord. Chem. Rev. 76 (1987), 121.

[2] I.G. Dance, Polyhedron 5 (1986), 1037-1104.

[3] M. Satoh, N. Nishimura, Y. Kanayama, A. Naganuma, T. Suzuki and C. Tohyama, J. Pharmacol. Exp. Ther. 283 (1997), $1529-1533$

[4] C.H. Kim, S. Parkin, M. Bharara and D. Atwood, Polyhedron 21 (2002), 225.

[5] M.S. Bharara, T.H. Bui, S. Parkin and D. Atwood, Dalton Trans. (2005), 3874.

[6] M.S. Bharara, T.H. Bui, S. Parkin and D.A. Atwood, Inorg. Chem. 44 (2005), 5753.

[7] M.S. Bharara, S. Parkin and D.A. Atwood, Inorg. Chem. 45 (2006), 2112-2118.

[8] M.S. Bharara, S. Parkin and D.A. Atwood, Inorg. Chem. 45 (2006), 7261-7268.

[9] Z. Popovic, G. Pavlovic, D. Matkovic-Calogovic, Z. Soldin, M. Rajic, D. Vikic-Topic and D. Kovacek, Inorg. Chim. Acta 306 (2000), 142-152.

[10] B. Hultberg, A. Andersson and A. Isaksson, Toxicology 156 (2001), 93.

[11] N.J. Brown, Trends Biochem. Sci. 10 (1985), 400.

[12] G. Henkel and B. Krebs, Chem. Rev. 104 (2004), 801.

[13] J.G. Wright, M.J. Natan, F.M. MacDonnell, D.M. Ralston and T.V. O'Halloran, Prog. Inorg. Chem. 29 (1990), 323.

[14] E.S. Gruff and S.A. Koch, J. Am. Chem. Soc. 112 (1990), 1245-1247.

[15] F. Jalilehvand, B.O. Leung, M. Izadifard and E. Damian, Inorg. Chem. 45 (2006), 66.

[16] G.A. Neville and T. Drakenberg, Can. J. Chem. 52 (1974), 616-622.

[17] Y.K. Sze, A.R. Davis and G.A. Neville, Inorg. Chem. 14 (1975), 1969.

[18] A.L. Presa, M. Capdevila and P.G. Duarte, Eur. J. Biochem. 271 (2004), 4872.

[19] M.M. Shoukry, Trans. Met. Chem. 15 (1990), 1.

[20] L. Carlton and D. White, Polyhedron 9 (1990), 2717-2720.

[21] F. Zintl and I. Persson, Inorg. Chim. Acta 131 (1987), 21-26.

[22] F.A. Cotton and G. Wilkinson, Basic Inorganic Chemistry, 5th edn, Wiley-Interscience, New York, NY, 1988.

[23] V. Mah and F. Jalilehvand, J. Biol. Inorg. Chem. 13 (2008), 541.

[24] B.V. Cheesman, A.P. Arnold and D.L. Rabenstein, J. Am. Chem. Soc. 110 (1988), 6359.

[25] M.M. Shoukry, B.V. Cheesman and D.L. Rabenstein, Can. J. Chem. 66 (1988), 3184-3189.

[26] T. Alsina, W. Clegg, K.A. Fraser and J. Sola, Chem. Commun. (1992), 1010.

[27] N. Govindaswamy, J. Moy, M. Millar and S.A. Koch, Inorg. Chem. 31 (1992), 5343.

[28] G. Krauter, B. Neumuller, V.L. Goedken and W.S. Rees Jr., Chem. Mater. 8 (1996), 360-368.

[29] A.W.D. Philip, J.J. Vittal and Y. Wu, Inorg. Chem. 33 (1994), 2180.

[30] G. Henkel, P. Betz and B. Krebs, Inorg. Chim. Acta 134 (1987), 195.

[31] G. Henkel, P. Betz and B. Krebs, J. Chem. Soc. Chem. Commun. (1985), 1498.

[32] J.M. Bramlett, H. Im, X. Yu, T. Chen, H. Cai, L.E. Roecker, C.E. Barnes, S. Dai and Z. Xue, Inorg. Chim. Acta 357 (2004), 243.

[33] A. Terzis, J.B. Faught and G. Pouskoulelis, Inorg. Chem. 19 (1980), 1060.

[34] A.J. Canty, C.L. Raston and A.H. White, Aust. J. Chem. 32 (1979), 311.

[35] P. Biscarini, E. Foresti and G. Pradella, J. Chem. Soc. Dalton Trans. (1984), 953.

[36] K. Nomiya, K. Tsuda and N.C. Kasuga, J. Chem. Soc. Dalton Trans. (1998), 1653-1659.

[37] P.J. Berrie, A. Gyani, M. Motevalli and P. O'Brien, Inorg. Chem. 32 (1993), 3862.

[38] S. Marchal, V. Moreno, G. Aullon, S. Alvarez, M. Quiros, M. Font-Bardia and X. Solans, Polyhedron 18 (1999), 36753682. 


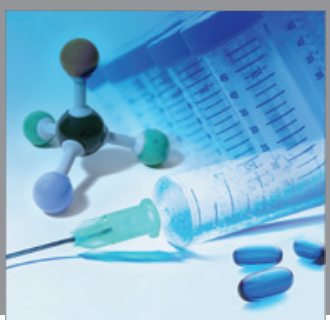

International Journal of

Medicinal Chemistry

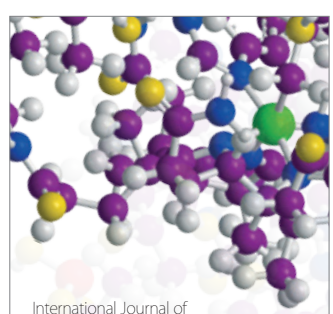

Carbohydrate Chemistry

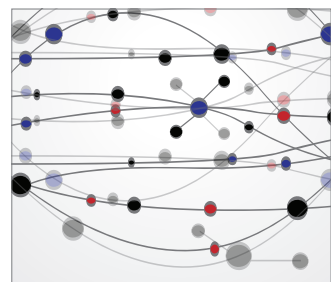

The Scientific World Journal
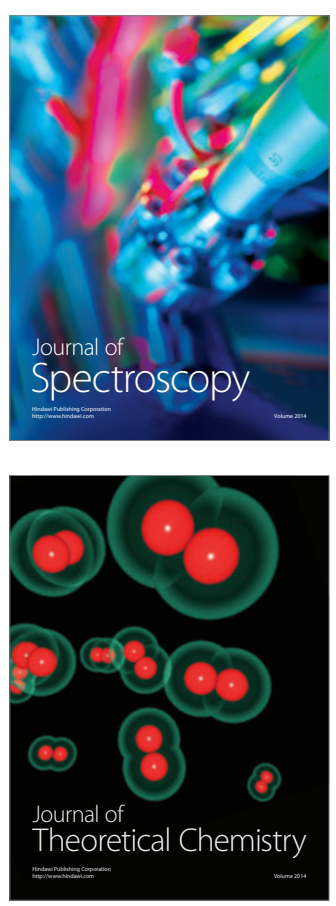
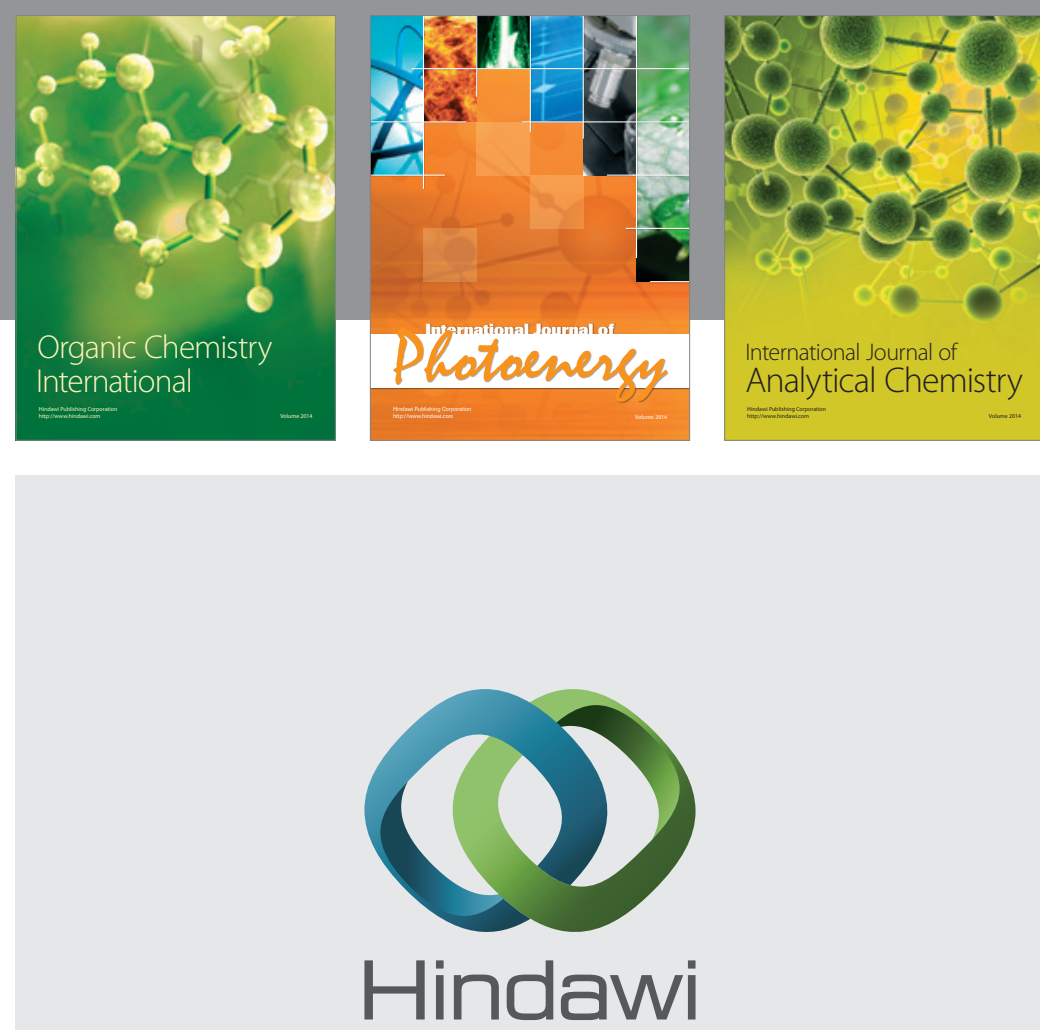

Submit your manuscripts at

http://www.hindawi.com
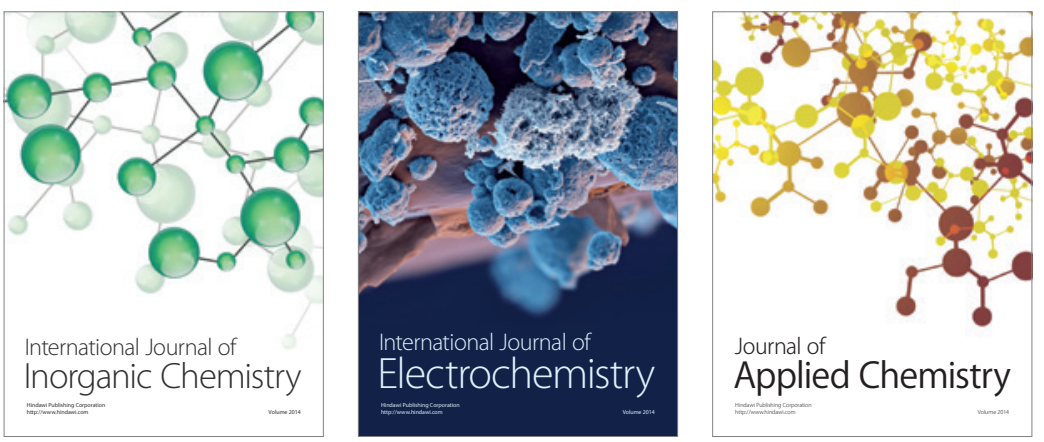

Journal of

Applied Chemistry
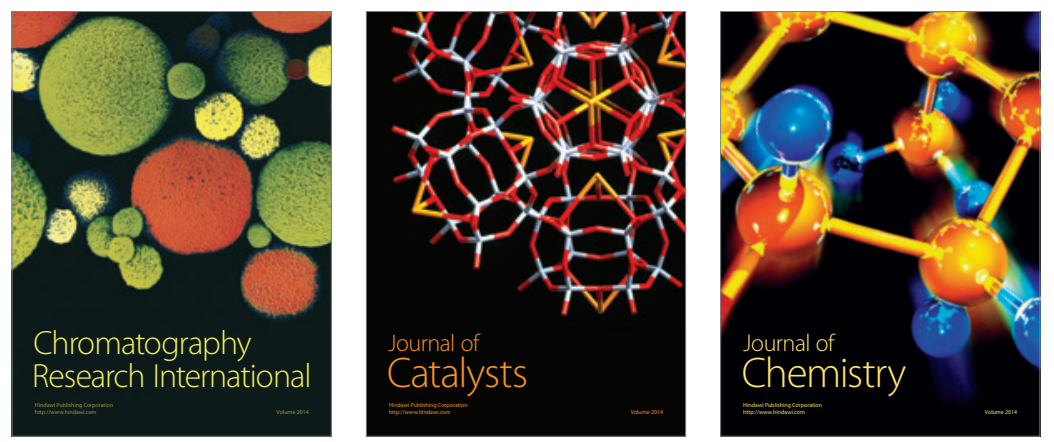
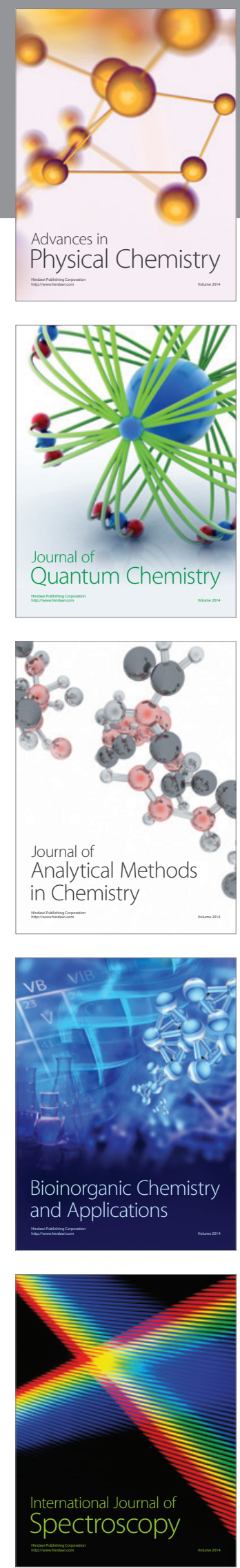